\title{
STUDI POLA RUANG LUAR PADA KEGIATAN BUDAYA DI HUTA SIALLAGAN
}

\author{
Yeremia Jodie B $^{(1)}$, Shanty Silitonga, ST.,MT ${ }^{(2)}$, Emmy Aritonang, ST., MT. ${ }^{(3)}$ \\ (1) Mahasiswa, Prodi Arsitektur, Fakultas Teknik, Universitas Katolik Santo Thomas Sumatera Utara \\ (2) Staff Pengajar, Prodi Arsitektur, Fakultas Teknik, Universitas Katolik Santo Thomas Sumatera Utara \\ Email: shanty.silitonga@gmail.com

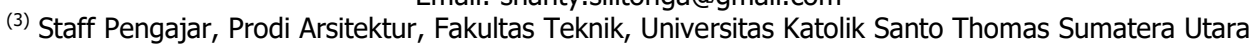

\begin{abstract}
The society of Batak Toba in Huta Siallagan has customs inherited by their ancestors, where there are customs and cultural patterns in the outer space including cultural ceremonies, customs and traditions. Based on the phenomenon found in the tourist village of Huta Siallagan, the researcher examines a culture pattern that has been formed and has its own attraction in the form of cultural tourism that makes it as one of tourism assets based on the potential of rural areas. Qualitative descriptive research strategy is where qualitative research is rooted in the natural setting as a whole, relying on human as a research tool, utilizing qualitative methods and conducting inductive data analysis. Qualitative research is concerned with the process rather than results. Desiring the limits of the research on the basis of the focus that arises as a problem, has a set of criteria for measuring the validity of data through agreement between the researcher and the subjects studied and descriptive studies trying to describe and interpret what is and can be about the conditions or relationships that exist, , ongoing processes, effects, or growing trends. Descriptive studies are primarily concerned with the present, although it is not uncommon to take into account past events and their effects on current conditions on the pattern of outer space on cultural activities occurring in Huta Siallagan
\end{abstract}

Keywords : Outer Space, Cultural Ceremonies, Huta Siallagan

\begin{abstract}
Abstrak
Masyarakat Batak Toba di Huta Siallagan memiliki adat istiadat yang diwariskan oleh nenek moyangnya, dimana terdapat adat istiadat dan pola budaya pada ruang luar termasuk upacara- upacara kebudayaan, kebiasaan dan tradisi. Berdasarkan fenomena yang terdapat di desa wisata Huta Siallagan, Peneliti meneliti sebuah pola kebudayaan yang selama ini terbentuk dan memiliki daya tarik tersendiri dalam bentuk wisata budaya yang menjadikannya sebagai salah satu aset kepariwisataan yang berbasis potensi daerah pedesaan. Strategi penelitian Kualitatif Deskriptif adalah dimana penelitian kualitatif berakar pada latar alamiah sebagai keutuhan, mengandalkan manusia sebagai alat penelitian, mamanfaatkan metode kualitatif dan mengadakan analisis data secara induktif. Penelitian kualitatif lebih mementingkan proses dari pada hasil. Menghendaki adanya batas penelitian atas dasar fokus yang timbul sebagi masalah, memiliki seperangkat kriteria untuk mengukur keabsahan data melalui kesepakatan antara peneliti dengan subyek yang diteliti dan studi deskriptif berusaha mendeskripsi dan menginterpretasi apa yang ada serta bisa mengenai kondisi atau hubungan yang ada, pendapat yang sedang tumbuh, proses yang sedang berlangsung, akibat efek yang terjadi, atau kecendrungan yang tengah berkembang. Studi deskriptif terutama berkenaan dengan masa kini, meskipun tidak jarang juga memperhitungkan peristiwa masa lampau dan pengaruhnya terhadap kondisi masa kini tentang pola ruang luar pada kegiatan budaya yang terjadi di Huta Siallagan
\end{abstract}

Kata Kunci: Ruang Luar, Kegiatan Budaya, dan Huta Siallagan 


\section{Pendahuluan}

Kegiatan budaya di suatu daerah menjadi daya tarik tersendiri bagi wisatawan karena budaya dari berbagai daerah memiliki keunikan yang berbeda yang tidak dimiliki oleh daerah lainnya. Kebudayaan ini merupakan keseluruhan yang kompleks yang mencakup pengetahuan, kepercayaan, kesenian, moral, hukum, adat istiadat dan kemampuan- kemampuan lain serta kebiasaan yang didapat oleh manusia sebagai anggota masyarakat dimana pariwisata tidak hanya memperkenalkan budaya bangsa dan tanah air, tetapi sektor ini memberikan lapangan kerja dan bidang usaha yang cukup luas. Para wisatawan yang datang ke suatu daerah atau negara, dikarenakan terdapat daya tarik budayanya dimana pada kawasan tersebut jauh berbeda dari budaya mereka, atau sebaliknya pada tempat yang jauh berbeda lalu ditemukan budaya yang sama.

Masyarakat Batak Toba di Huta Siallagan memiliki adat istiadat yang diwariskan oleh nenek moyangnya. Adat istiadat dalam hal kegiatan budaya pada ruang luar termasuk upacara- upacara kebudayaan yang disepakati menjadi tradisi dan berlaku secara umum di masyarakat serta tradisi yang menjadikannya seperti adat, kepercayaan, kebiasaan, upacara dan sebagainya yang secara turun temurun diwariskan. Dalam hal ini adat istiadat di daerah ini merupakan salah satu bentuk atraksi wisata budaya yang dikembangkan di kawasan pedesaan.

Wisatawan yang berwisata ke desa wisata akan mendapatkan pengalaman melihat dan mengapresiasi keunikan kehidupan dan tradisi masyarakat dengan segala potensinya. Desa wisata tersebut menjadikan salah satu aset kepariwisataan yang berbasis pada potensi daerah pedesaan dengan segala keunikan dan daya tariknya yang dapat diberdayakan dan dikembangkan sebagai produk wisata untuk menarik kunjungan wisatawan ke lokasi desa tersebut. Dalam hal ini setiap tempat maupun objek wisata mempunyai keunikan tersendiri dimana Penulis meneliti sebuah fenomena di desa wisata Huta Siallagan yang mempunyai pola ruang luar dimana terdapat kegiatan budaya yang memiliki daya tarik tersendiri dalam bentuk wisata serta menjadikannya sebagai salah satu aset kepariwisataan yang berbasis pada potensi daerah pedesaan.

\section{Landasan Teori}

\subsection{Pengertian Ruang Luar}

Menurut Prabawasari, V. W., \& Suparman, A. Tata Ruang Luar (1999), Terdapat beberapa pengertian mengenai ruang luar, antara lain:

- Ruang yang terjadi dengan membatasi alam hanya pada bidang alas dan dindingnya, sedangkan pada bidang atapnya, tidak terbatas.

- $\quad$ Sebagai lingkungan luar buatan manusia, yang mempunyai arti dan maksud tertentu dan sebagai bagian dari alam.

Arsitektur tanpa atap, tetapi dibatasi oleh dua bidang, yaitu dinding dan lantai atau ruang yang terjadi dengan menggunakan dua elemen pembatas. Hal ini menyebabkan lantai dan dinding menjadi elemen yang penting dalam merencanakan ruang luar. Ruang luar memiliki fungsi sebagai wadah dari aktivitas di ruang terbuka, sirkulasi antar bangunan, jalur masuk ke dalam bangunan dan parkir. Ruang luar dipengaruhi terutama oleh konteks lingkungan alami, lingkungan terbangun serta fungsi bangunan dalam tapak.

\subsection{Proses Terjadinya Ruang Luar}

Menurut Prabawasari, V. W., \& Suparman, A. Tata Ruang Luar (1999), Terdapat beberapa hal yang menyebabkan terbentuknya ruang luar. Ruang luar terbentuk karena adanya ruang mati, ruang terbuka dan ruang positif. Berikut adalah penjelasan bagaimana ruang-ruang tersebut dapat membentuk ruang luar

1. Ruang Mati

Ruang mati merupakan kebalikan dari ruang hidup. Ruang hidup adalah ruang yang memiliki bentuk dah hubungan yang benar serta komposisi dan struktur yang direncanakan dengan baik. Sedangkan ruang mati adalah ruang yang terbentuk dengan tidak direncanakan, tidak terlingkup 
dan tidak dapat digunakan dengan baik. (ruang yang terbentuk tidak dengan disengaja atau ruang yang tersisa).

\section{2. $\quad$ Ruang Terbuka}

Ruang terbuka merupakan suatu wadah yang dapat menampung kegiatan masyarakat baik secara individu maupun kelompok. Bentuk ruang terbuka tergantung pada pola dan susunan masa bangunan. Terdapat beberapa batasan pola ruang terbuka antara lain :

- Bentuk dasar daripada ruang terbuka di luar bangunan

- Dapat digunakan oleh publik (setiap orang)

- Memberi kesempatan untuk bermacam-macam kegiatan

\section{Ruang Positif}

Ruang positif merupakan ruang terbuka yang diolah dengan peletakan massa bangunan atau objek pelingkup yang menimbulkan sifat positif. Biasanya terdapat kepentingan manusia di dalamnya. Sedangkan ruang negatif merupakan ruang terbuka yang menyebar dan tidak berfungsi dengan jelas

\section{4. $\quad$ Ruang Negatif}

Ruang negatif terjadi secara spontan dan pada awalnya tidak dimaksudkan untuk kegiatan manusia. Setiap ruang yang tidak direncanakan, tidak dilingkupi atau tidak dimaksudkan untuk kegiatan manusia merupakan ruang negatif.

\subsection{Elemen Ruang Luar}

Menurut Prabawasari, V. W., \& Suparman, A. Tata Ruang Luar (1999) dalam ruang luar, terdapat elemen-elemen perancangan secara visual yang menonjol pada area ruang luar tersebut dibatasi menjadi 3 (tiga), antara lain :

\subsubsection{Bangunan}

Bangunan juga memiliki peranan cukup dalam menentukan kualitas uang luar karena bangunan merupakan elemen dinding pada ruang luar ini dapat menentukan batas ruang luar dan mengatur keterlingkupan ruang luar sesuai dengan derajat keterlingkupan yang diinginkan. Sebaliknya bila perletakan bangunan tidak baik maka ruang luar menjadi tidak terbatas sehingga menjadi luas tak terhingga dan catering keperluan tidak tercipta.

\subsubsection{Vegetasi}

Bahan tumbuh tumbuhan menciptakan suatu ikatan di antara orang orang dengan alam, tampak lembut efek efek yang kadang kadang tidak terpikirkan pada gerak maju dan membuat kota kota besar pun lebih menyenangkan untuk didiami. Tumbuh tumbuhan dapat menegaskan ruang dengan menciptakan massa atau rongga, dengan membingkai ruang ruang atau pemandangan dengan bertindak sebagai suatu latar belakang bagi suatu karakter tapak yang menarik, atau berkurang sebagai satu titik fokus. Vegetasi merupakan unsur pembentuk struktur ke ruangan atau spasial yang dapat menentukan ukuran dan terutama kualitas ruang.

\subsubsection{Sirkulasi}

Alur sirkulasi dapat diartikan sebagai tali yang mengikat ruang ruang suatu bangunan atau suatu deretan ruang ruang dalam maupun luar, menjadi saling berhubungan. Kita merasakan ruang ketika kita berada di dalamnya dan ketika kita meletakkan tujuan. 


\subsection{Pengertian Kegiatan dan Budaya}

Kata "Kebudayaan" berasal dari (bahasa Sanskerta) yaitu "Buddayah" yang merupakan bentuk jamak dari kata "Budhi"yang berarti budi atau akal. Kebudayaan diartikan sebagai "hal-hal yang bersangkutan dengan budi atau akal".

Menurut Prof. Dr. Koentjaraningrat, IImu Antropologi (1990) Kebudayaan merupakan suatu tindakan berpola dari manusia dalam sebuah masyarakat. Wujud ini sering disebut dengan sistem sosial. Sistem sosial ini terdiri dari aktivitas-aktivitas manusia yang saling berinteraksi, mengadakan kontak, serta bergaul dengan manusia lainnya menurut pola-pola tertentu yang berdasarkan adat tata kelakuan. Sifatnya konkret, terjadi dalam kehidupan sehari-hari, dan dapat diamati dan didokumentasikan.

\subsection{Kegiatan Budaya Pada Ruang Luar}

Kelompok kekerabatan suku bangsa Batak berdiam di daerah pedesaan yang disebut Huta. Biasanya satu Huta didiami oleh keluarga dari satu marga. Ada pula kelompok kerabat yang disebut marga taneh yaitu kelompok pariteral keturunan pendiri dari huta. Marga tersebut terikat oleh symbol-simbol tertentu misalnya nama marga. Dalam marga tadi merupakan kerabat patrilineal yang masih berdiam dalam satu kawasan. Sebaliknya anggota yang sudah banyak hidup tersebar sehingga tidak saling kenal tetapi mereka dapat mengenali anggotanya melalui nama marga yang selalu disertakan dibelakang nama kecilnya, Status sosial orang Batak didasarkan pada empat prinsip yaitu : perbedaan tingkat umur, perbedaan pangkat dan jabatan, perbedaan sifat keaslian dan, status kawin. Berikut merupakan sistem kekerabatan dari suku Batak. Terdapat 3 tradisi budaya yang dilakukan pada ruang luar yang dilakukan oleh Suku Batak di Huta Siallagan yaitu Kelahiran, Pernikahan, dan Kematian beserta upacara adat yang dilakukan antara lain :

\subsubsection{Upacara Masa Kehamilan sampai Kelahiran}

Upacara kehamilan merupakan suatu upacara yang penting di didalam daur hidup tradisi suku batak toba. Menurut D. Sinaga, Upacara Tradisional daerah Sumatera Utara, (1985) Beberapa upacara ini diawali ketika sang ibu memasuki kehamilan ke 7 bulan dengan maksud dan tujuan sebagai ungkapan wujud syukur kepada yang maha kuasa yaitu antara lain Upacara Mangirdak, Upacara Ulos Tondi, Upacara Martutu Aek dan Upacara Mangharoan.

\subsubsection{Upacara Pernikahan}

Upacara pernikahan merupakan suatu upacara yang penting di didalam daur hidup tradisi suku batak toba. Upacara ini pada masyarakat Batak Toba sangat penting sebagai ungkapan sukacita keluarga karena salah satu anggota keluarganya melangsungkan pernikahan dimana terdapat dua keluarga yang disatukan yaitu antara lain Upacara Marhusip, Upacara Marhata Sinamot, Upacara Martumpol, Upacara Marunjuk dan Upacara Mangulosi.

\subsubsection{Upacara Kematian}

Pada masyarakat Batak Toba apabila seseorang meninggal pada usia tua (Saurmatua) pada umumnya akan dilaksanakan upacara kematian. Kehadiran kerabat Dalihan Natolu sangat di perlukan. Maka Daliha Na Tolu inilah yang mengatur dan menjalankan perannya tersebut sehingga acara berjalan dari awal hingga akhir, khususnya baik didalam upacara kegiatan adat maupun dalam perlakuan seharihari itu tidak akan menyimpang dari adat yang telah ada.

Pelaksanaan upacara tergantung kepada lamanya mayat disemayangkan. Idealnya apabila semua putra-putri dari yang Mate Saur Matua dan pihak hula-hula (saudara laki-laki dari pihak istri) telah hadir. Pada masyarakat Batak Toba Upacara Kematian Saur Matua ini membutuhkan persiapan yang sangat matang dari segi materi karena untuk menghormati nenek moyang mereka yang telah lebih dahulu menghadap sang Khalik mereka harus mengorbankan seekor kerbau sebagai lambang bahwa yang meninggal sudah Saur Matua. Ada banyak jenis kematian pada adat suku Batak, diantaranya adalah Upacara di Jabu dan Upacara Marlaman. 


\section{Metodologi}

Penelitian ini menggunakan metode deskriptif dengan pendekatan kualitatif. Menurut John Creswell dalam Dr. Jr Raco, Metode Penlitian Kualitatif (2010) penelitian kualitatif berakar pada latar alamiah sebagai keutuhan, mengandalkan manusia sebagai alat penelitian, mamanfaatkan metode kualitatif dan mengadakan analisis data secara induktif. Penelitian kualitatif lebih mementingkan proses dari pada hasil. Menghendaki adanya batas penelitian atas dasar fokus yang timbul sebagi masalah, memiliki seperangkat kriteria untuk mengukur keabsahan data melalui kesepakatan antara peneliti dengan subyek yang diteliti.

Metode yang digunakan untuk memperoleh atau mengumpulkan data dalam penelitian ini adalah melalui studi literature, pengamatan (observasi), wawancara, dan dokumentasi.

\subsection{Metode Analisa Data}

Penelitian ini memakai metologi analisis deskriptif yang dilakukan dengan cara :

1. Mengkaji hasil pengamatan dilapangan.

2. Mengkaji teori yang berkaitan dengan elemen ruang luar dan kegiatan budaya di Huta Bolon

3. Melaksanakan Penelitian dengan cara:

a. Membuat format penelitian dalam bentuk tabel.

b. Menganalisa data dengan teori yang diterapkan

c. Membuat kesimpulan.

d. Membuat laporan.

\section{Analisa}

\subsection{Analisa Bangunan}

Bangunan menunjukkan ukuran dimensi antara elemen bangunan atau ruang dengan suatu elemen tertentu dengan ukurannya. Analisa ini menjelaskan menghubungkan bangunan atau ruang dengan kemampuan dalam memahami bangunan atau ruang tersebut. Berikut beberapa objek bangunan pada lingkup di Huta Siallagan

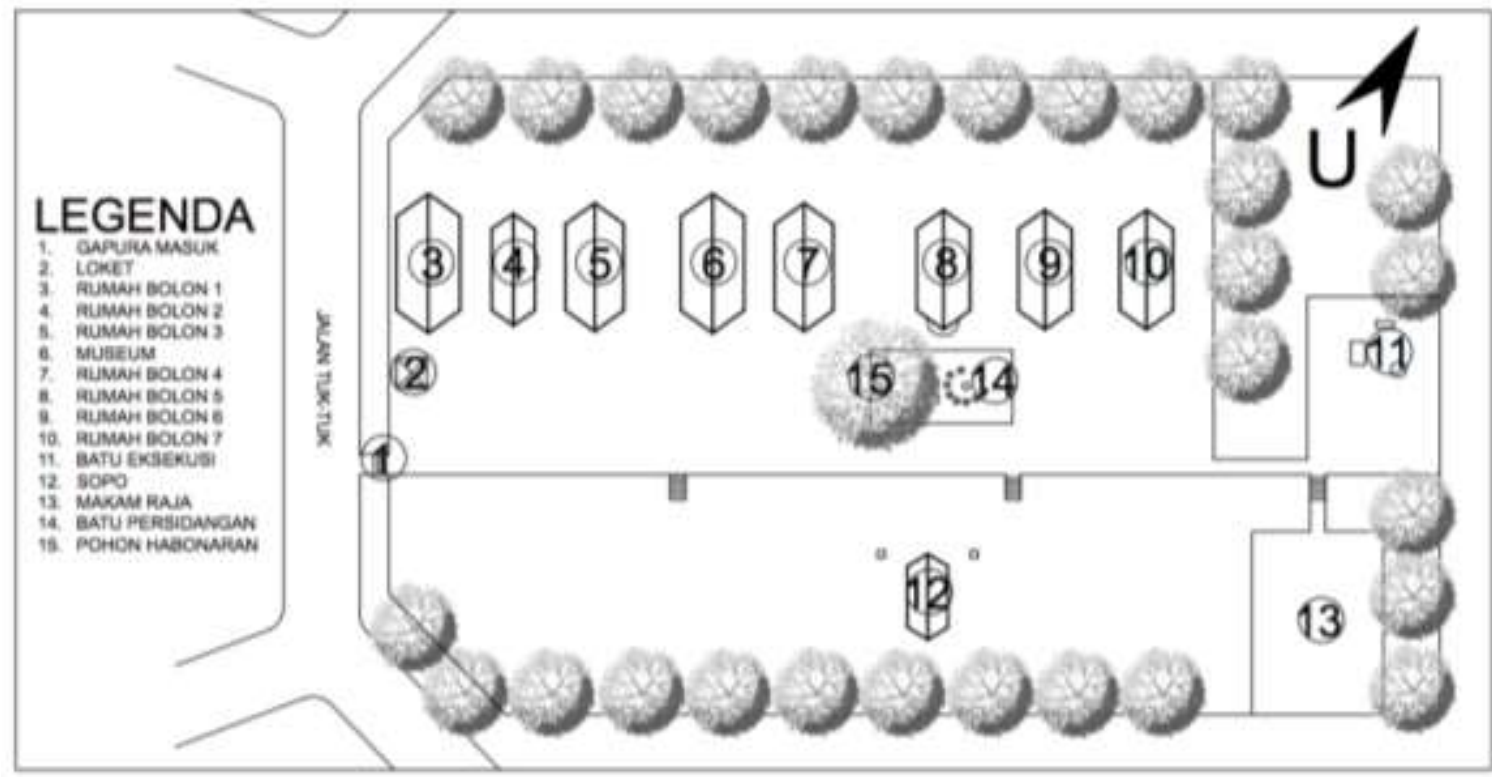

Gambar 1.1 Analisa Bangunan

Sumber : Peneliti, 2017 
4.2. Analisa Upacara Kelahiran (Upacara Mangirdak)
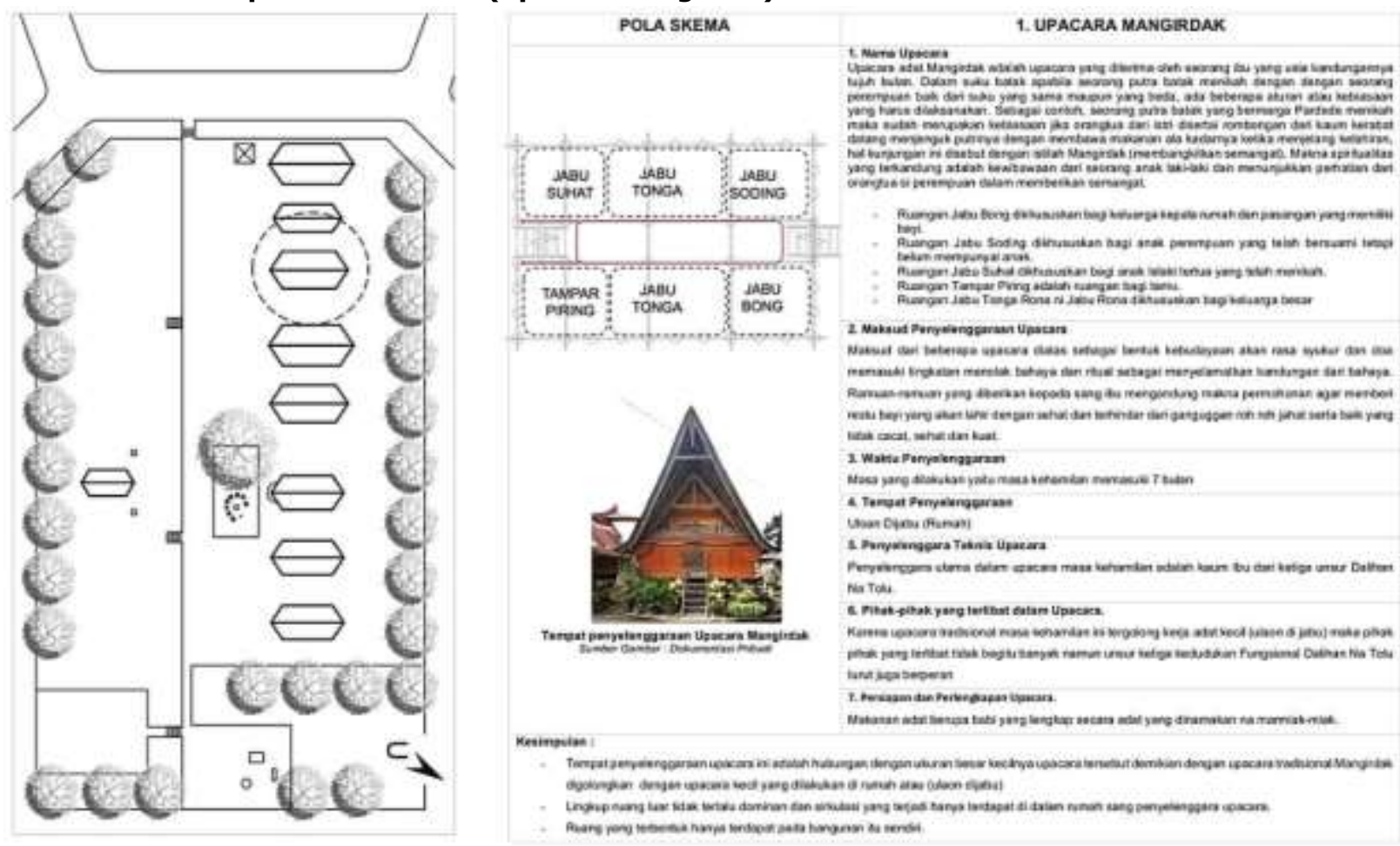

4.3. Analisa Upacara Kelahiran (Upacara Ulos Tondi)

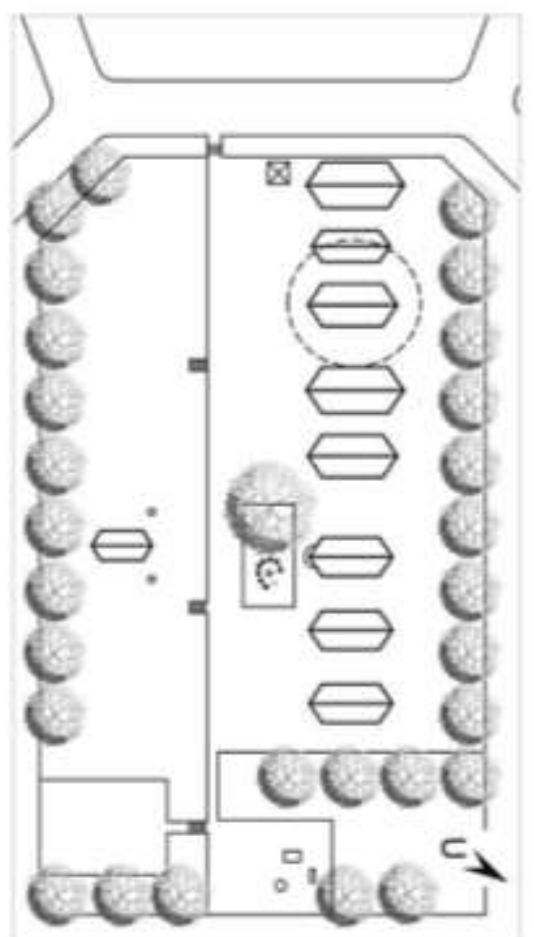

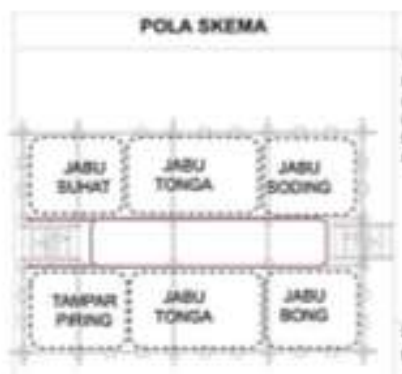

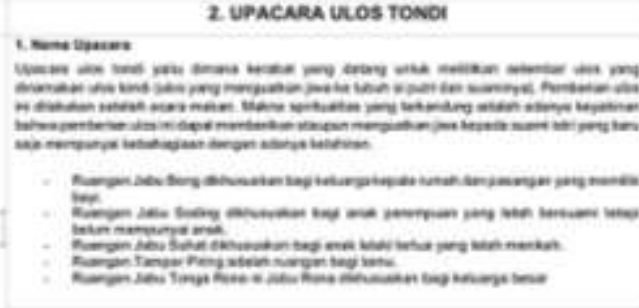

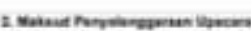

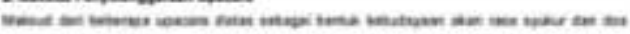

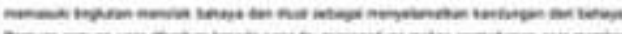

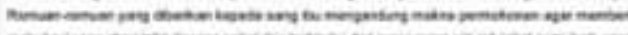

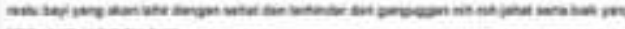

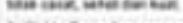

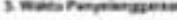

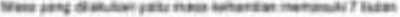

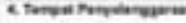

the bisming

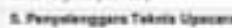

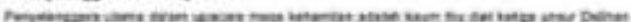

atat

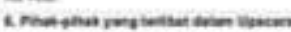

- wown.

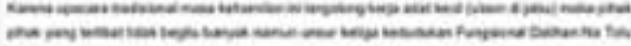

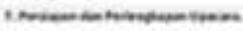

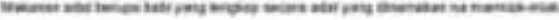

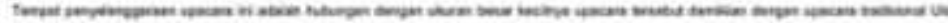

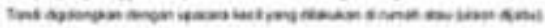

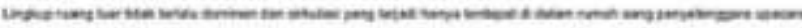

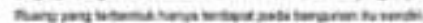




\subsection{Analisa Upacara Kelahiran (Upacara Martutu Aek)}
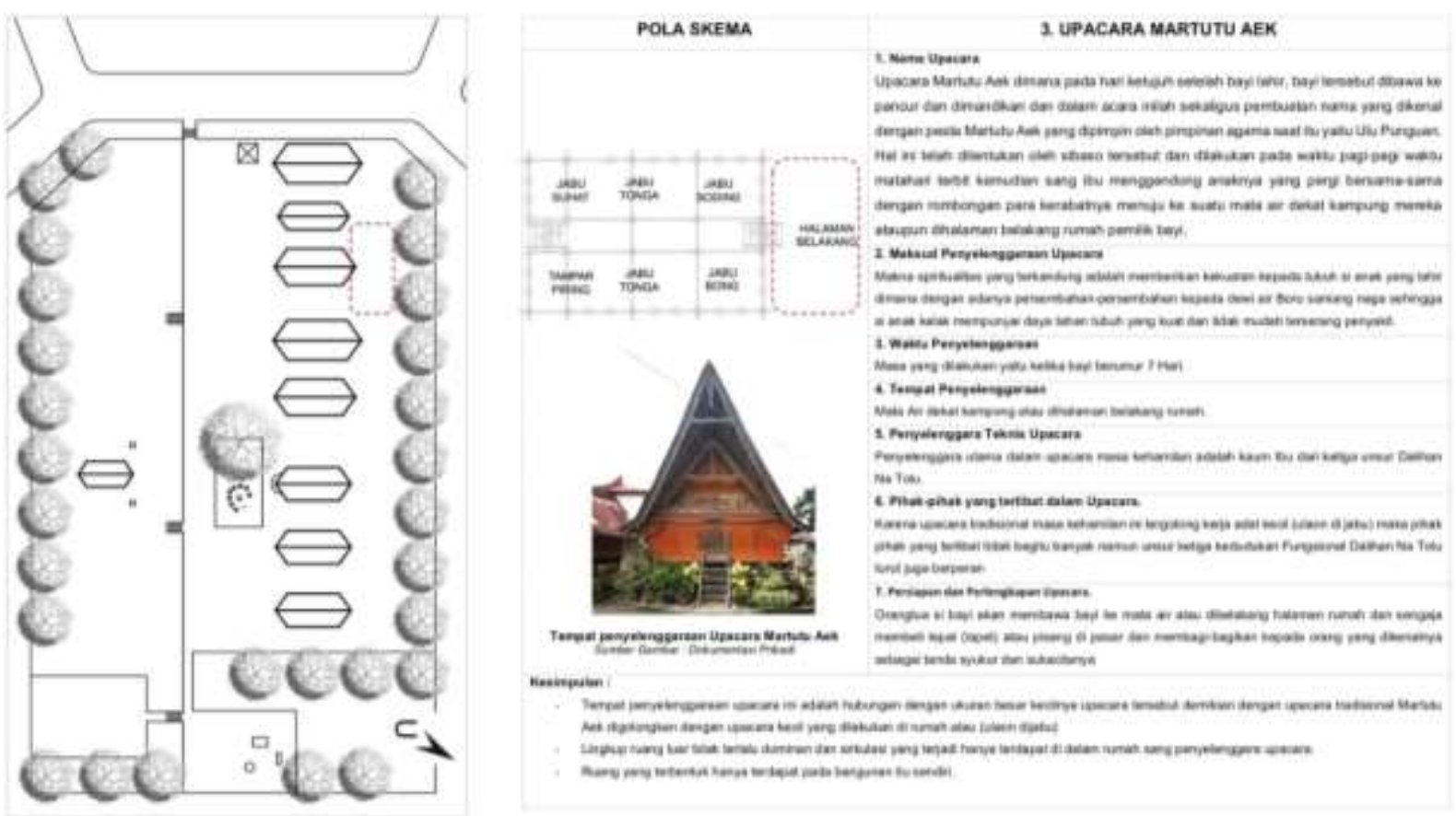

4.5. Analisa Upacara Kelahiran (Upacara Mangharoan)
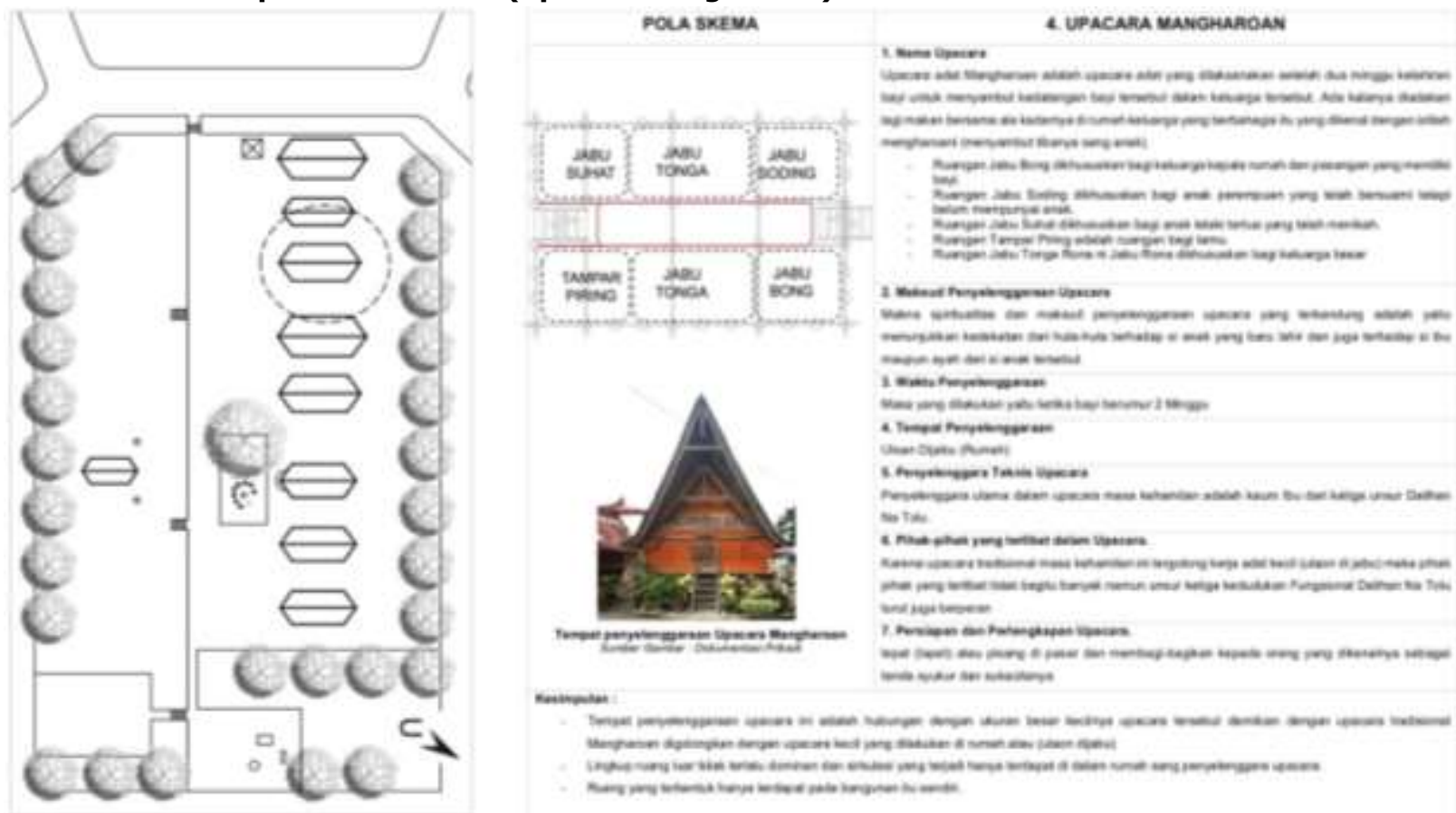
4.6. Analisa Upacara Pernikahan (Upacara Marhusip)
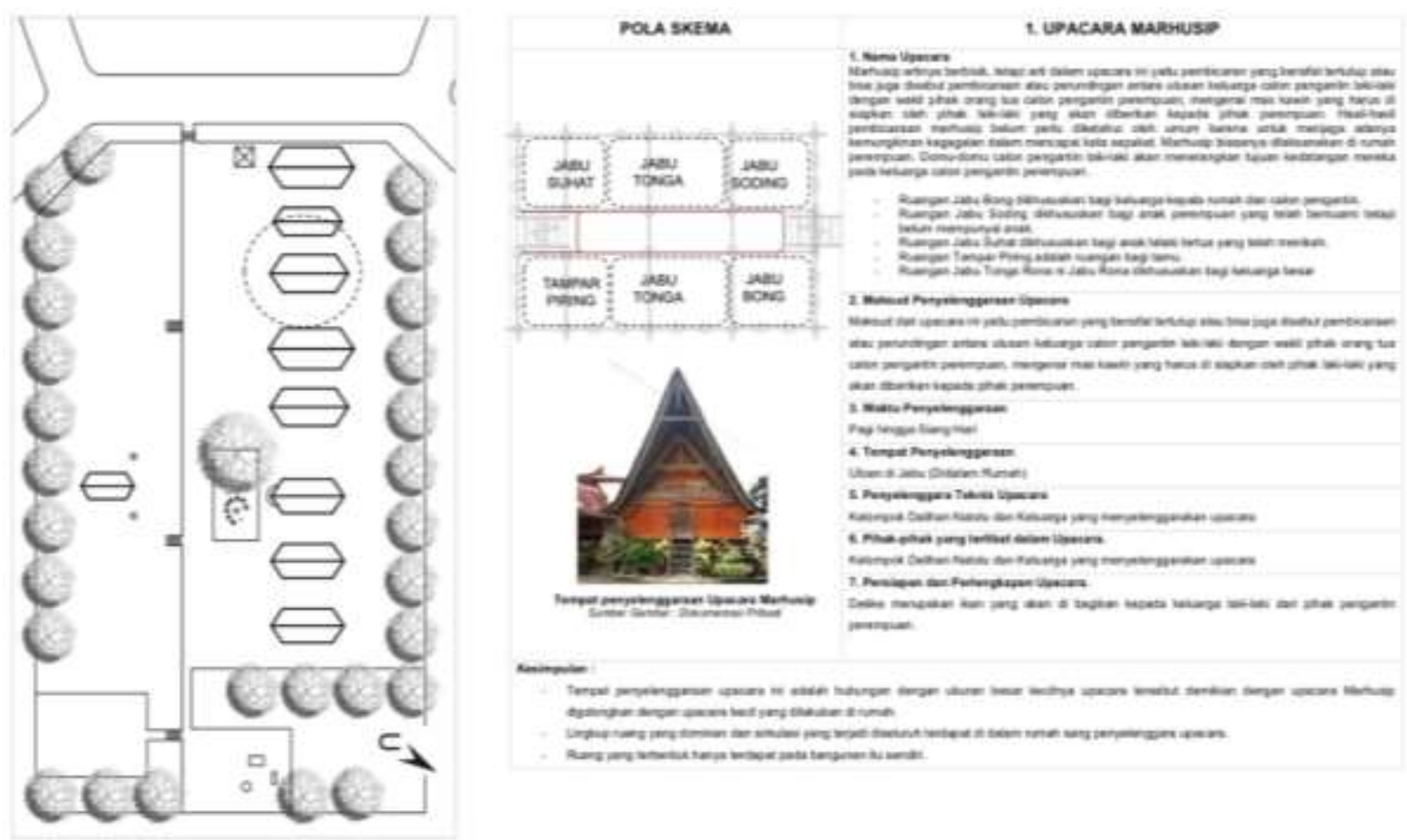

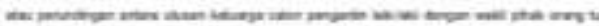

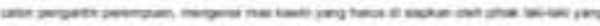

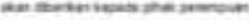

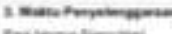

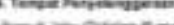

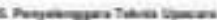

(6)

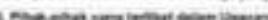

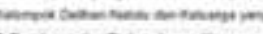

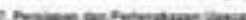

tom inger

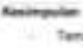

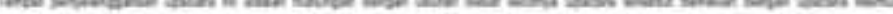

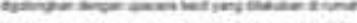

-

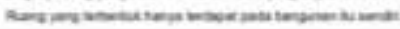

\subsection{Analisa Upacara Pernikahan (Upacara Marhata Sinamot)}
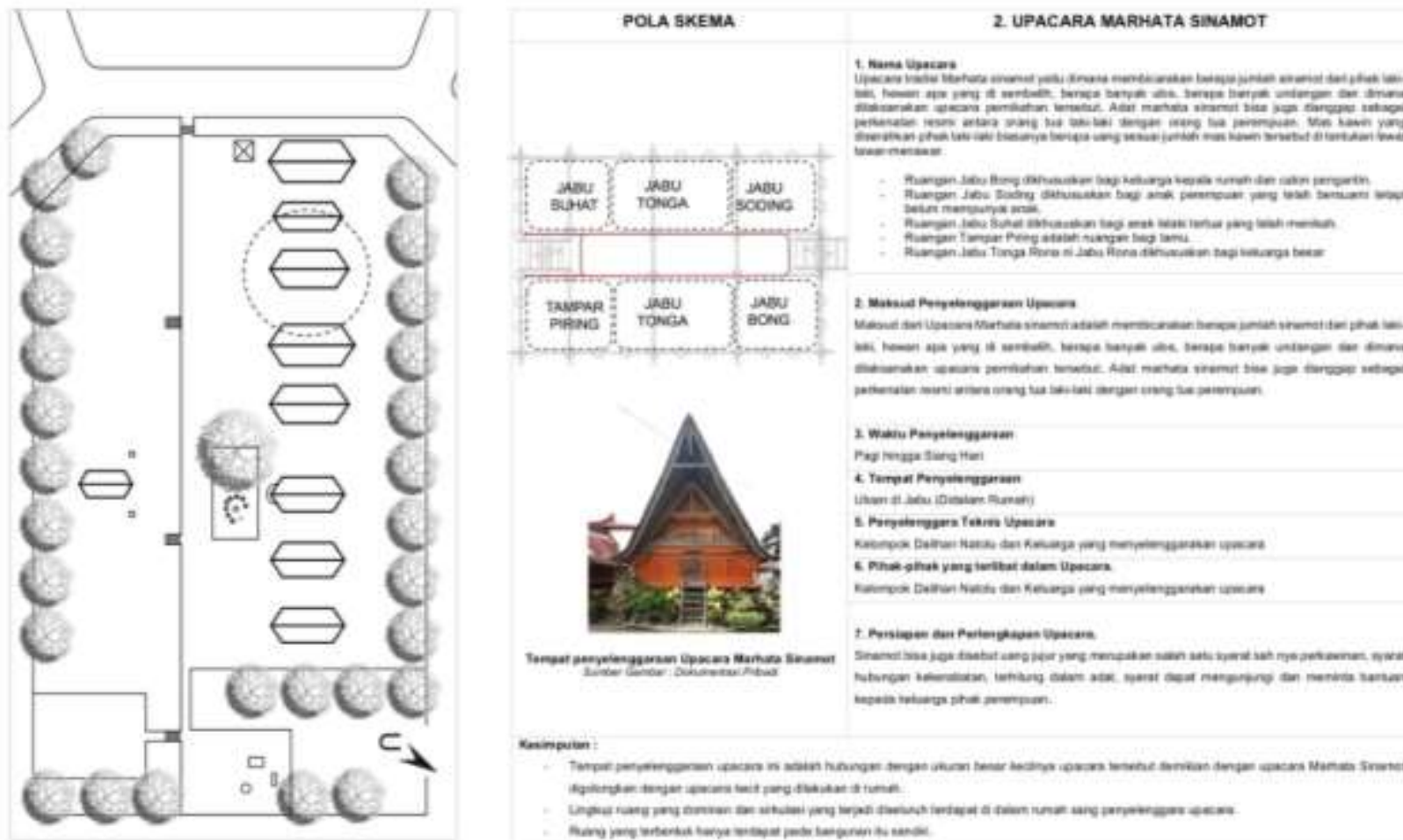

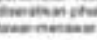

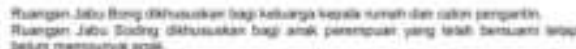

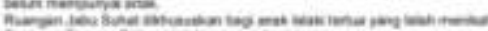

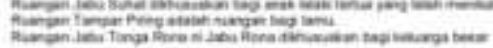

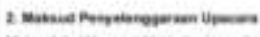

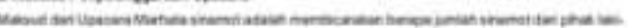

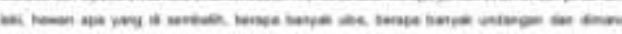

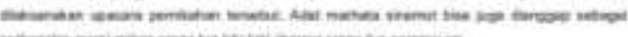

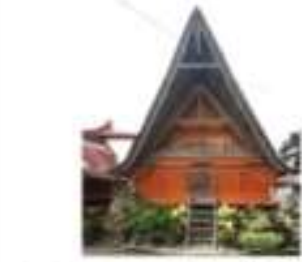

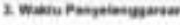

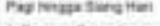

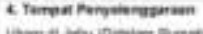

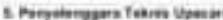

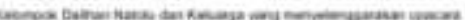

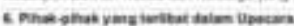

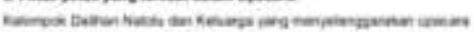

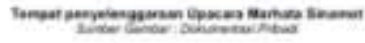

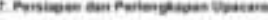

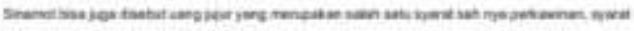

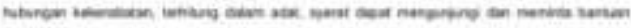

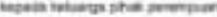

Nompout :

Tre

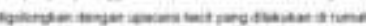

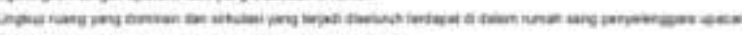

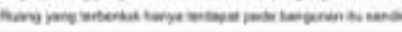




\subsection{Analisa Upacara Pernikahan (Upacara Martumpol)}
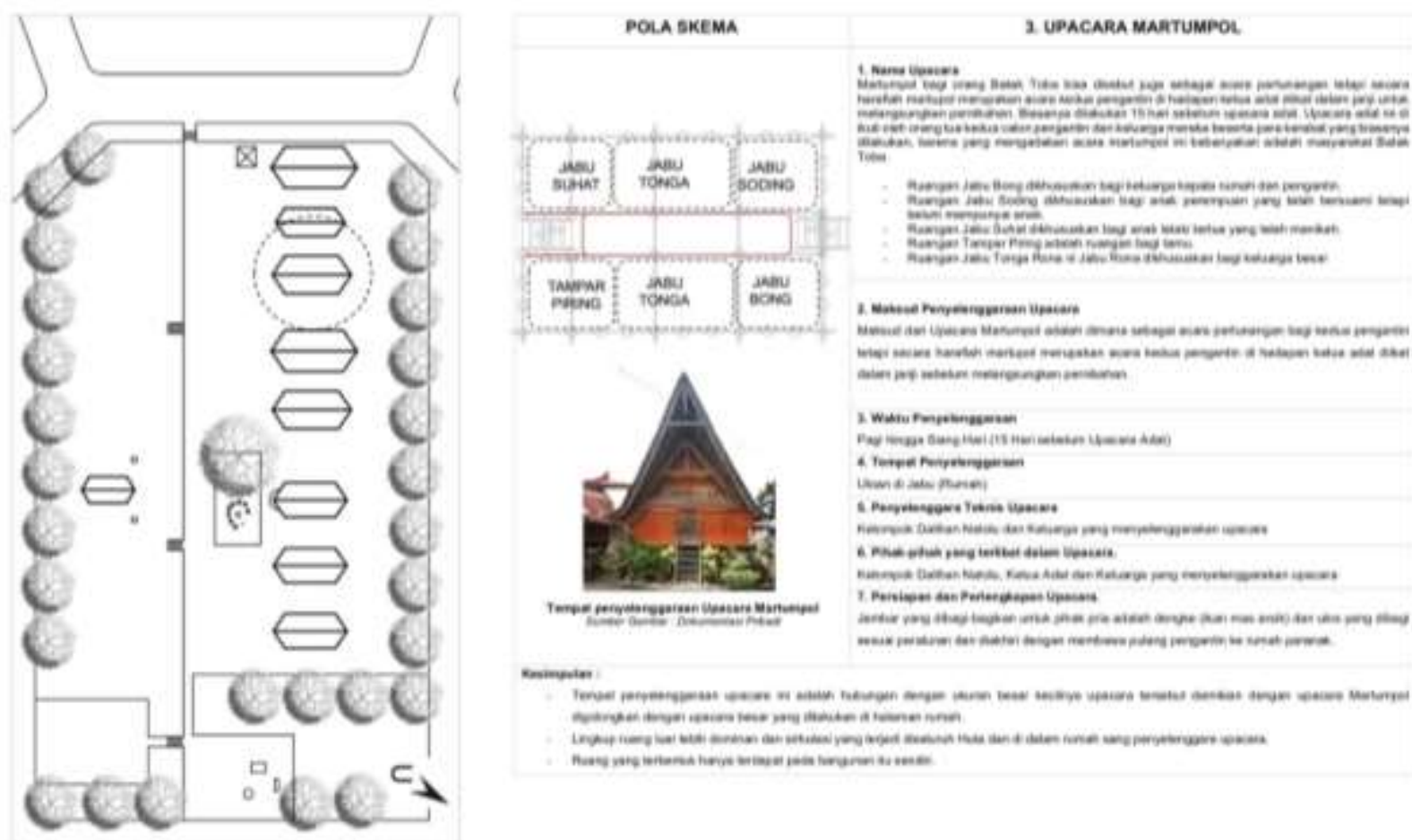

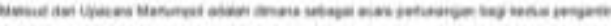

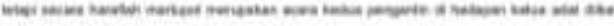

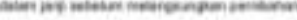

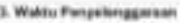

(1)

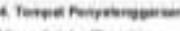

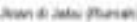

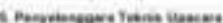

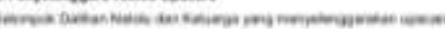

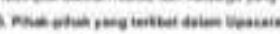

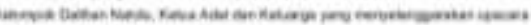

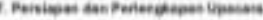

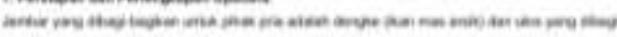

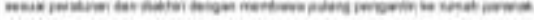

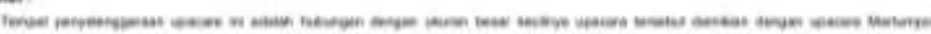

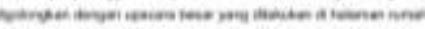

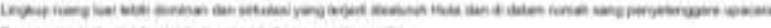

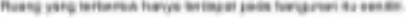

\subsection{Analisa Upacara Pernikahan (Upacara Marunjuk)}
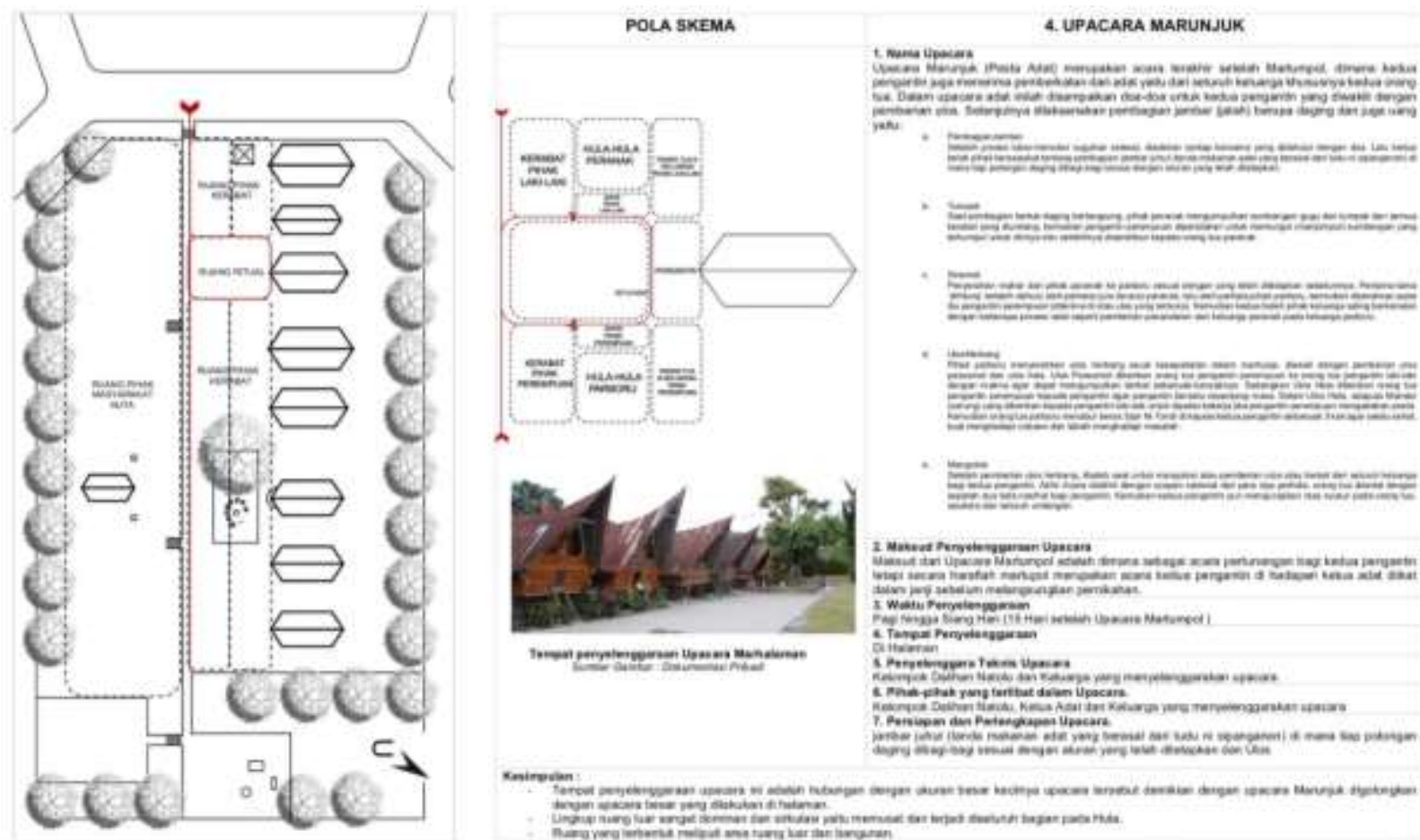

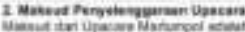

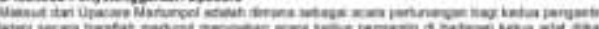

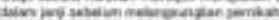

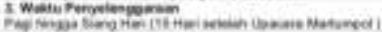

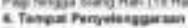

giltion

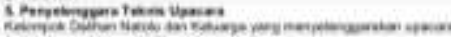

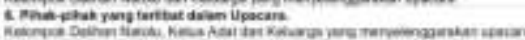

(1)

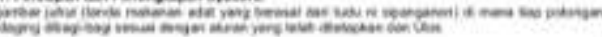

coniswoun

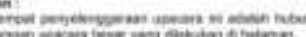




\subsection{Analisa Upacara Kematian (Upacara Uloan di Jabu)}
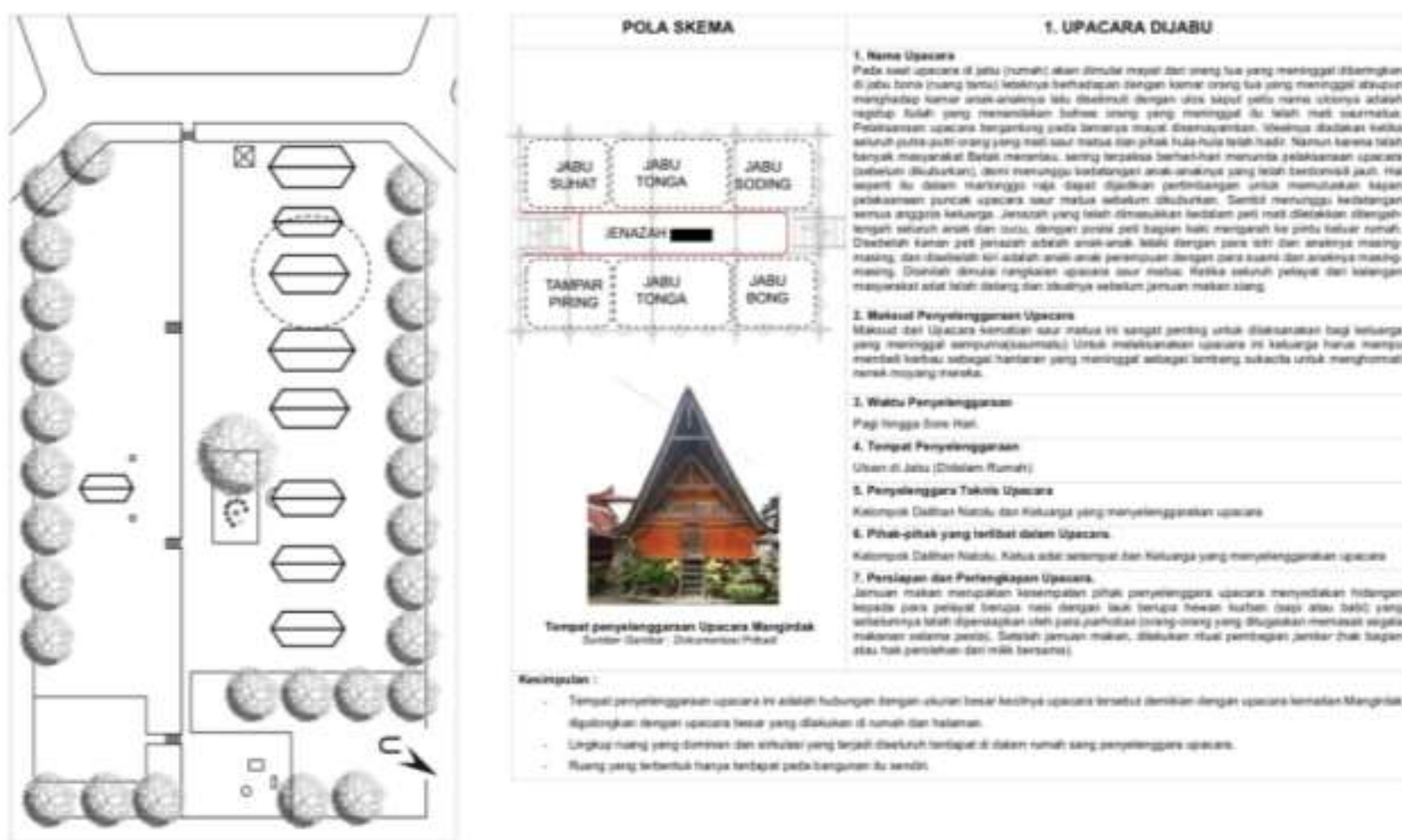

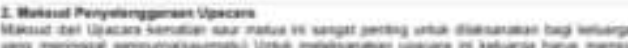

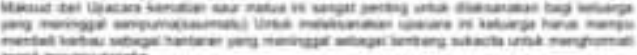

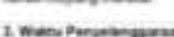

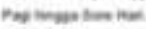

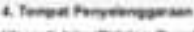

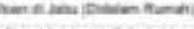

vacer.

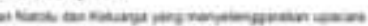

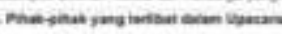

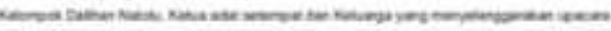

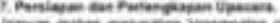

-

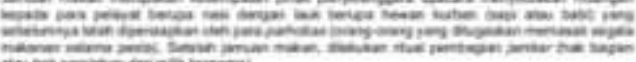
Nominition

Terom

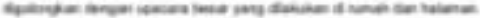

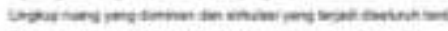

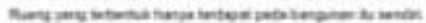

\subsection{Analisa Upacara Kematian (Upacara Marhalaman)}
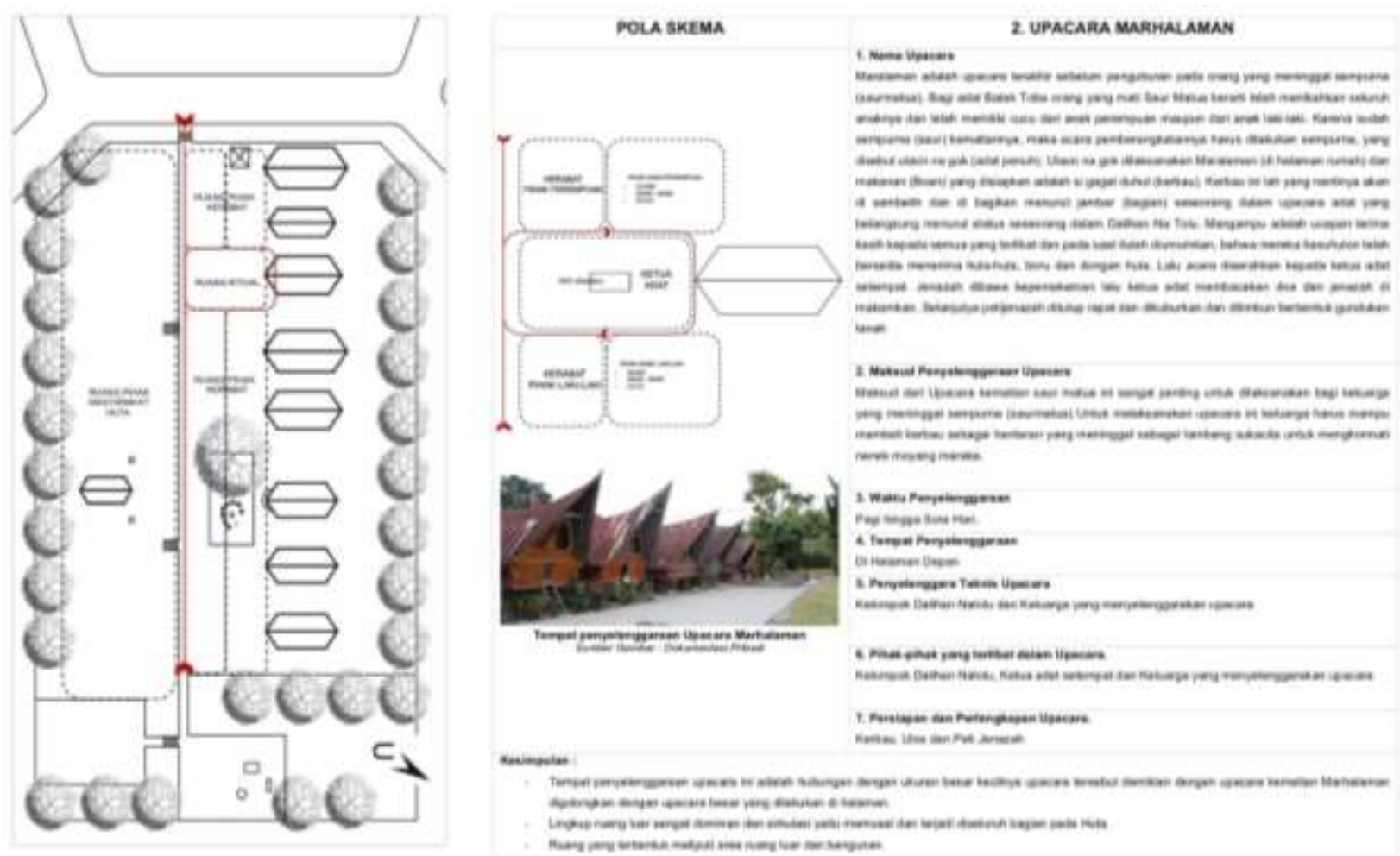


\section{Kesimpulan dan Saran}

5.1. Kesimpulan

a. Secara umum masyarakat Batak Toba di Huta Siallagan hanya melakukan 2 Upacara besar diruang luar yaitu Upacara Pernikahan dan Kematian yang telah dilakukan serta disepakati menjadi tradisi yang berlaku secara umum di kehidupan masyarakat setempat serta menjadikannya sebagai adat, kepercayaan, kebiasaan, yang dilakukan secara turun temurun dan telah diwariskan. Dalam hal ini kegiatan budaya di Huta Siallagan merupakan salah satu bentuk atraksi wisata budaya yang dikembangkan di kawasan pedesaan.

b. Dalam aspek pembentuk ruang luar

- Bangunan yang ada di dalam Huta Siallagan sangat berpengaruh pada kegiatan Upacara pada masyarakat Batak dimana bangunan juga sebagai tempat tinggal serta memiliki peranan cukup dalam menentukan aspek pembentuk ruang luar karena bangunan merupakan elemen dinding pada ruang luar yang menentukan batas ruang luar dan mengatur kegiatan yang akan dilakukan pada ruang luar.

- Vegetasi merupakan unsur pembentuk ruang luar pada Huta Siallagan dimana dijadikan pembatas antara Huta dan lingkup pada kawasan diluar Huta.

c. Dalam aspek sirkulasi,

- Pencapaian menuju kedalam tempat upacara pada Huta Siallagan yaitu Langsung dimana suatu pencapaian yang mengarah langsung ke suatu tempat masuk melalui sebuah jalan yang segaris dengan sumbu bangunan. Tujuan visual dalam seluruhnya dari semua bangunan atau tempat masuk yang dipertegas.

- Kemudian Pintu Masuk Bangunan hanya mempunyai satu pintu masuk pada Huta Siallagan dimana untuk memasuki sebuah bangunan, sebuah ruang dalam bangunan, atau satu kawasan dibatasi ruang luar, melibatkan kegiatan menembus bidang vertikal yang memisahkan sebuah ruang dari lainnya dan memisahkan keadaan di sini dan di sana.

- Konfigurasi Alur Gerak pada Huta Siallagan bersifat Linier dimana alur masuk pada huta diawali titik awal menuju ke huta dan melewati deretan ruang ruang pada lingkup huta.

- Bentuk ruang dan sirkulasi pada Huta Siallagan yaitu bersifat terbuka/open space, dimana ruang luar menjadi perluasan fisik dari ruang yang ditembusnya. serta memberikan kontinuitasvisual/ruangan dengan ruang-ruang yang dihubungkan.

\subsection{Saran}

Dalam mendeskripsi dan menganalisa pola kegiatan budaya yang ada di Huta Siallagan bisa dilihat mengenai kondisi dan hubungan adat istiadat yang ada dan terjadi dan dilakukan hingga saat ini, meskipun jaman semakin maju dan berkembang, proses adat istiadat di Huta Siallagan masih terjaga dengan baik, meskipun efek modernisasi yang terjadi saat ini, masyarakat di desa ini tetap memperhitungkan peristiwa masa lampau dan pengaruhnya terhadap kondisi masa kini. Dalam hal ini, masyarakat di Huta Siallagan saat ini masih melestarikan adat, kepercayaan dan kebiasaan dengan mengambil nilai-nilai yang baik sebagai identitas yang telah diwariskan oleh suku batak toba di Kabupaten Samosir. 


\section{Daftar Pustaka}

D.K Ching, Francis (2008). Bentuk Ruang dan Tatanan. Penerbit Erlangga, Jakarta.

John Creswell dalam Dr. Jr Raco (2010). Metode Kualitatif. Penerbit Grasindo, Jakarta.

Koentjaraningrat, Prof. Dr (1990). I/mu Antropologi. Penerbit Rineka Cipta, Jakarta.

Napitupulu S.P (1997). Aristektur Tradisional daerah Sumatera Utara. Penerbit Departemen Pendidikan dan Kebudayaan, Medan.

Prabawasari dan Suparman (1999). Tata Ruang Luar. Penerbit Gundarma, Jakarta.

Sinaga, D. (1985). Upacara Tradisional daerah Sumatera Utara. Penerbit Departemen Pendidikan dan Kebudayaan, Medan. 